\title{
Non-occlusive mesenteric ischemia during treatment for ketoacidosis associated with acute onset type 1 diabetes mellitus: a case report
}

\author{
Kazunobu Une ${ }^{1}$, Yusuke Sumi ${ }^{1}$, Manabu Kurayoshi ${ }^{1}$, Ryuichi Nakanuno ${ }^{1}$, and Masahiro \\ Nakahara $^{1}$
}

\section{${ }^{1}$ JA Onomichi General Hospital}

February 22, 2022

\begin{abstract}
This case report describes a patient with non-occlusive mesenteric ischemia that developed due to diabetic ketoacidosis. We believe that early diagnosis and intervention may improve the prognosis of non-occlusive mesenteric ischemia that has low vascular risk, with the major risk factor being dehydration due to diabetic ketoacidosis.
\end{abstract}

\section{Hosted file}

main_document.docx available at https://authorea.com/users/344456/articles/557426-nonocclusive-mesenteric-ischemia-during-treatment-for-ketoacidosis-associated-with-acuteonset-type-1-diabetes-mellitus-a-case-report

\section{Hosted file}

figure1.docx available at https://authorea.com/users/344456/articles/557426-non-occlusivemesenteric-ischemia-during-treatment-for-ketoacidosis-associated-with-acute-onset-type1-diabetes-mellitus-a-case-report

\section{Hosted file}

Figure2.docx available at https://authorea.com/users/344456/articles/557426-non-occlusivemesenteric-ischemia-during-treatment-for-ketoacidosis-associated-with-acute-onset-type1-diabetes-mellitus-a-case-report

\section{Hosted file}

table.1.docx available at https://authorea.com/users/344456/articles/557426-non-occlusivemesenteric-ischemia-during-treatment-for-ketoacidosis-associated-with-acute-onset-type1-diabetes-mellitus-a-case-report 